\title{
PERAN PENGAWAS PENDIDIKAN DALAM PENINGKATAN MUTU PENDIDIKAN SMP DI KABUPATEN BIMA PROVINSI NUSA TENGGARA BARAT
}

\author{
Dedi Iskandar, Udik Budi Wibowo \\ SMP Negeri 1 Sape-Bima \\ Email: dedi.iskandar22@gmail.com
}

\begin{abstract}
Abstrak
Penelitian ini bertujuan untuk memperoleh gambaran objektif dan komprehensif tentang proses perekrutan pengawas pendidikan dan peran pengawas pendidikan, serta mengetahui faktor-faktor penghambat dan pendukung peran pengawas untuk meningkatkan mutu pendidikan SMP di Kabupaten Bima Provinsi Nusa Tenggara Barat. Penelitian ini menggunakan pendekatan penelitian kualitatif dengan metode studi kasus. Data dikumpulkan melalui wawancara, observasi dan studi dokumen. Tahapan analisis data menggunakan model interaktif dan analisis komponensial. Hasil penelitian menemukan: (1) proses perekrutan pengawas pendidikan belum sepenuhnya sesuai dengan peraturan pemerintah dan undang-undang. (2) pemantauan pelaksanaan program sekolah yang dilakukan pengawas pendidikan belum terlaksana dengan optimal. (3) supervisi yang dilakukan pengawas pendidikan belum terlaksana dengan optimal. (4) evaluasi program kerja sekolah yang dilakukan pengawas pendidikan sudah terlaksana dengan baik. (5) pembuatan laporan hasil pemantauan, supervisi, dan evaluasi yang dilakukan pengawas pendidikan terlaksana dengan baik. (6) Tindak lanjut yang dilakukan pengawas pendidikan belum optimal. Selanjutnya yang menjadi (7) faktor penghambat adalah: (a) letak geografis, (b) akses jalan, (c) fasilitas, (d) penguasaan teknologi, (e) sumber daya manusia; dan (8) faktor pendukung adalah: (a) dana operasional tambahan dari Pemerintah Daerah, (b) ketersediaan motor dinas, (d) pelatihan, (e) keterlibatan masyarakat, (f) tempat domisili pengawas pendidikan, (g) siswa, (h) semangat dalam diri pengawas pendidikan.
\end{abstract}

Kata kunci: pengawas pendidikan, mutu pendidikan, Kabupaten Bima

\section{THE ROLE OF EDUCATIONAL SUPERVISOR IN IMPROVING EDUCATION QUALITY OF SECONDARY SCHOOLS IN BIMA, WEST NUSA TENGGARA PROVINCE}

\begin{abstract}
This study aims to analyze and obtain comprehensive and objective description of recruiting process of educational supervisor, the role of educational supervisor, also to know the obstacles and supporting factors of educational supervisor roles to improve the education quality of secondary schools in Bima, West Nusa Tenggara. This is a qualitative approach with case study method. The data were collected through interviews, observation and document study. The phase of data analysis used by interactive model and componential analysis. The results showed: 1) the recruitment process of educational supervisor in Bima was not based on goverment rules and law. 2) monitoring of scholl programmes implementation by educational supervisor ran less optimal. 3) supervising by educational supervisor ran less optimal. 4) evaluating of school programmes undertaken by educational supervisor has ran well. 5) reporting about the results of monitoring, supervising, and evaluating, was done well. 6) the follow up of the results of supervision was not optimal. 7) some obstacles factors are: a) geographical area, b) highway access, c) facilities, d) mastery of information and technology, e) human resources. Then, some
\end{abstract}


supporting factors are: a) operational funds form local government, b) vehicle, c) coaching, d) the involvement of communities, e) educational supervisor domicile, e) students, f) spirit of the educational supervisor itself.

Keywords: Educational supervisor, education quality, Bima

\section{PENDAHULUAN}

Pendidikan merupakan usaha yang dilakukan dengan sengaja dan sistematis untuk memotivasi, membina, membantu serta membimbing seseorang dalam mengembangkan segala kompetensinya sehingga mampu mencapai kualitas diri yang lebih baik. Pendidikan bukan suatu produk yang langsung jadi, tapi pendidikan merupakan suatu proses dan layanan. Proses dan layanan akan berjalan baik bila semuanya sepakat, bahwa pendidikan harus dibangun sejalan antara pembangunan fisik dan ketersediaan tenaga pendidik dan kependidikan yang bermutu sehingga mampu mendukung proses layanan pendidikan sesuai dengan apa yang diharapkan. Mengacu pada Undang-Undang Nomor 32 Tahun 2004 tentang Pemerintah Daerah dan Peraturan Pemeritah Nomor 25 Tahun 2000 tentang Kewenangan Pusat dan Provinsi sebagai daerah otonom telah mendorong perubahan besar pada sistem pengelolaan pendidikan di Indonesia. Oleh karena itu, pengelolaan pendidikan bukan merupakan tanggung jawab pemerintah pusat melainkan tanggung jawab pemerintah daerah.

Pendidikan pada masa desentralisasi berbeda dengan sentralisasi. Pada masa sentralisasi segala sesuatu seperti: pengangkatan pengawas, penganggaraan dana operasional pengawas, pengangkatan kepala sekolah, penetapan jumlah murid, fasilitas dan sarana/prasarana sekolah sebagian besar ditetapkan oleh pemerintah secara sentral. Sedangkan, pendidikan pada masa desentralisasi menjadi sedikit berbeda. Hal tersebut dikarenakan pendidikan bukan hanya menjadi tanggung jawab pemimpin ataupun pimpinan dalam suatu lembaga tetapi menjadi tanggung jawab bersama untuk memberikan kontribusi positif dalam peningkatan mutu pendidikan. Oleh karena itu, aktor pendidikan seperti guru, kepala sekolah, pengawas pendidikan dan dewan pendidikan dalam menjalankan tugas dan fungsinya diharapkan mampu bersinergi sebagai suatu sistem yang utuh sehingga dapat menciptakan pendidikan yang berkualitas.

Tugas terpenting pengawas pendidikan idealnya mampu memberikan alternatif pemecahan masalah dalam pembelajaran. Hal ini tidak terlepas dari peran pengawas pendidikan sebagaimana diuraikan Wiles \& Bondi (1986:104) bahwa peran pengawas pendidikan adalah “...to help teachers and other education leaders understand issues and make wise decisions affecting student education". Pendapat tersebut dapat di artikan bahwa peran pengawas pendidikan adalah membantu guru dan pemimpin pendidikan untuk memahami isu-isu dan membuat keputusan yang bijak yang mempengaruhi pendidikan siswa. Pengawas memiliki kiprahnya sangat strategis dalam meningkatkan mutu pendidikan dengan tugas yang diembanya antara lain membimbing, membina, memantau, supervisi, mengevaluasi, membuat laporan serta menindaklanjuti hasil supervisi.

Namun, di lain pihak, jika ditelisik lebih mendalam tentang peran pengawas pendidikan pada otonomi daerah sekarang ini, terdapat ketidaktepatan bahkan sering terjadi ketimpangan-ketimpangan yang menimbulkan kerancuan mulai dari perekrutan pengawas sekolah sampai pada peran pengawas pendidikan dalam melaksanakan tugas pokok dan fungsinya. Perekrutan pengawas pendidikan idealnya sudah tertulis dengan jelas pada Peraturan Menteri nomor 12 tahun 2007 tentang pengawas sekolah, namun hal tersebut 
menjadi sedikit berbeda karena proses perekrutan pengawas pendidikan di Kabupaten Bima sebagian direkrut melalui kebijakan dari pimpinan daerah.

Kemudian, hal lain yang terjadi berdasarkan data kebutuhan pengawas yang diperoleh dari DIKPORA Kabupaten Bima bahwa jumlah pengawas pendidikan pada tingkat SMP sebanyak 31 orang dengan jumlah guru sebanyak 2.364 sedangkan jumlah ideal yang dibutuhkan sebanyak 59 orang. Dari rasio jumlah pengawas pendidikan tersebut, terdapat pengawas pendidikan yang memiliki kualifikasi umur di bawah 50 tahun sebesar $26 \%$ dan di atas 50 tahun sebesar $74 \%$, kemudian pengawas pendidikan yang telah memenuhi kualifikasi pendidikan dengan tamatan S2 (magister) sebanyak 39\%, sementara yang berpendidikan S1 sebanyak 58\%, disamping itu terdapat pula yang lulusan D2 sebesar 3\%. Dari data tersebut menunjukan bahwa sumber daya manusia pengawas sekolah pada tingkat SMP di Kabupaten Bima dinilai masih kurang karena tidak sesuai dengan jumlah rasio guru. Kemudian, kualifikasi pendidikan yang bervariasi sehingga akan menghasilkan keberagaman output yang diharapkan.

Data tersebut mendeskripsikan bahwa kekurangan sumber daya manusia (pengawas sekolah) mengakibatkan intensitas kunjungan bervariasi pada masih-masing sekolah di distrik perkotaan dan terpencil, padahal secara keseluruhan sekolah mempunyai tujuan yang mulia untuk mencerdaskan anak bangsa. Dengan demikian idealnya pengawas pendidikan berkunjung pada sekolah binaan sesuai dengan beban kerja pengawas sebanyak 37,5 jam seminggu untuk melakukan pembimbingan dan pelatihan profesional guru dan pengawasan yang ekuivalensinya dengan 24 (dua puluh empat) jam pembelajaran tatap muka dalam 1 (satu) minggu.

Pada sisi lain, salah satu pokok permasalahan pengawas sekolah yakni perbedaan latar belakang pendidikan pengawas sekolah dengan guru yang disupervisi pada proses belajar mengajar. Hal ini terjadi karena pemerintah belum mengangkat pengawas dari spesifikasi jurusan khusus sehingga memungkinkan bahwa pola pengawasan bersifat administratif dan tidak substantif. Idealnya pengawas pendidikan harus mensupervisi guru sesuai dengan rumpun mata pelajaran yang sama sehingga mampu berperan aktif dalam meninjau proses belajar mengajar yang berlaku di sekolah dan membuat peta konsep tentang masalah-masalah yang dihadapi para guru dalam mengajarkan indikator pelajaran pada peserta didik, membina guru dalam membuat administrasi pelajaran serta membina guru dalam mengelola kelas ketiak kegiatan belajar mengajar berlangsung.

Berdasarkan beberapa hal tersebut bahwa intensitas kunjungan yang masih teramat minim pada sekolah binaan memungkinkan peran pengawas dalam memantau, mensupervisi, mengevaluasi, membuat laporan, dan menindak lanjuti hasil pengawasan (supervisi) berdampak kurang optimal sehingga ketertinggalan mutu pendidikan pada sekolah tidak mampu diatasi dengan mudah. Dengan demikian harapan terakhir dalam peningkatan mutu pembelajaran pada khususnya dan mutu pendidikan pada umumnya di lingkup Kabupaten masih perlu ditingkatkan.

Pengertian pengawas pendidikan

Pengawas pendidikan merupakan salah satu komponen yang memiliki peran penting dalam peningkatan mutu pendidikan. Alarcão (2007:110) menyatakan bahwa,

The supervisor is the person who creates the conditions for teachers to reflect and act in a collaborative manner, in a questioning and critical manner and with an investigative spirit, which is absolutely necessary nowdays. They do not to researchers in a truly academic sense, but must have an investigate spirit and must be able to 
carry out small scale research studies, since this is the only way towards attaining innovation and transformation.

Pemikiran tersebut diartikan bahwa supervisor adalah orang yang menciptakan kondisi bagi guru untuk merefleksikan dan bertindak secara kolaboratif, dengan cara menanyakan dan kritis dengan semangat investigasi, yang benar-benar diperlukan saat ini. Mereka tidak harus menjadi peneliti dalam bidang akademis yang sebenarnya, tetapi harus memiliki semangat investigasi dan harus mampu melaksanakan studi penelitian dalam skala kecil, karena ini adalah satu-satunya jalan menuju pencapaian inovasi dan transformasi.

Pendapat Alaracão tersebut, dipertegas oleh Barr (Sullivan \& Glanz, 2005:17) yang mana menguraikan tentang kemampuan pengawas dalam bidang pendidikan bahwa,

Supervisor must have ability to analize teaching situations and to locate the probable causes for poor work with a certain degree of expertness; they must have the ability to use an array of datagathering devices peculiar to the field of supervision itself; they must process certain constructive skills for the development of new means, methods, and materials of instruction; they must know how teachers learn to teach; they must have the ability to teach teachers how to teach; and they must be able to evaluate. In short, they must process training in both the science of instructing pupils and the science of instructing teachers. Both are included in the science of supervision.

Pandangan tersebut dapat diartikan bahwa pengawas harus memiliki kemampuan untuk menganalisa situasi pengajaran dan untuk menemukan penyebab kemungkinan pekerjaan yang buruk dengan tingkat keahlian tertentu, mereka harus memiliki kemampuan untuk menggunakan berbagai perangkat pengumpulan data khas pada bidang pengawasan itu sendiri, mereka harus memproses keterampilan konstruktif tertentu untuk pengembangan sarana baru, metode, dan bahan-bahan pengajaran; mereka harus tahu bagaimana guru belajar untuk mengajar, mereka harus memiliki kemampuan untuk mengajar guru bagaimana cara mengajar, dan mereka harus mampu mengevaluasi. Singkatnya, mereka harus memiliki keahlian baik dalam ilmu mengajar murid dan ilmu mengajar guru, yang mana keduanya tersebut termasuk dalam ilmu kepengawasan.

Pengawas mempunyai arti/definisi yang berbeda pada setiap pandangan ahli bahwa,

Supervisor of instruction whatever their titles, must lead more aggressively in the improvement of instruction. They must demonstrate competencies more adequately enter into collaborative arrangements that are genuinely cooperative and become involved in building instructional evaluation systems to guide the improvements process.

Pendapat tersebut dapat diartikan bahwa pengawas pengajaran yang memiliki gelar apapun, harus membina lebih agresif dalam peningkatan pengajaran. Mereka harus menunjukkan kompetensi yang lebih memadai dalam pengaturan yang benar-benar kooperatif dan terlibat dalam membangun sistem evaluasi pembelajaran untuk memandu proses perbaikan.

Berdasarkan definisi-definisi tersebut bahwa pengawasan tidak terlepas dari bagian fungsi manajemen, fungsi manajemen yang mempunyai hubungan erat dengan pengawasan dinamakan controlling (pengawasan). Dengan demikian dapat disimpulkan bahwa kepengawasan merupakan kegiatan atau tindakan pengawasan dari seseorang yang diberi tugas, tanggung jawab dan wewenang melakukan pembinaan dan penilaian terhadap orang dan atau 
lembaga yang dibinanya. Seseorang yang diberi tugas tersebut disebut pengawas harus benar-benar memahami perananya dan/atau memiliki keahlian dalam bidang pengawasan dalam usaha memberikan layanan kepada kepala sekolah, guru dan personil sekolah baik secara individual maupun secara kelompok dalam upaya memperbaiki pembelajaran yang pada akhirnya akan meningkatkan kinerja kepala sekolah, kinerja guru dan personil sekolah sehingga kemajuan anak dan mutu pembelajaran secara komprehensif akan dapat ditingkatkan.

Dimensi Kepengawasan Pendidikan Kiprah pengawas pendidikan menjadi bagian integral dalam peningkatan mutu pendidikan di sekolah sebagai hakikat pengawasan. Menurut Sudjana, et al. (2006:8) bahwa hakikat pengawasan memiliki empat dimensi: 1) support, 2) trust, 3) challenge; dan 4) networking and collaboration.

Keempat dimensi hakikat pengawasan itu masing-masing dijelaskan berikut ini. Dimensi pertama dari hakikat pengawasan yaitu dimensi support. Dimensi ini menunjuk pada hakikat kegiatan pengawasan yang dilakukan oleh supervisor dalam mendukung (support) pihak sekolah untuk mengevaluasi diri dalam kondisi yang sebenarnya. Oleh karena itu, supervisor bersama pihak sekolah dapat melakukan analisis kekuatan, kelemahan dan peluang serta ancaman bagi sekolah dalam peningkatan dan pengembangan mutu pendidikan pada sekolah di masa yang akan datang. Dimensi kedua dari hakikat pengawasan yaitu dimensi trust. Dimensi ini menunjuk pada hakikat kegiatan pengawasan yang dilakukan oleh supervisor dalam memberi kepercayaan (trust) stakeholder pendidikan dengan menggambarkan profil dinamika sekolah masa depan yang lebih baik dan lebih menjanjikan.

Dimensi ketiga dari hakikat pengawasan yaitu dimensi challenge. Dimensi tersebut menunjuk pada hakikat kegiatan pengawasan yang dilakukan oleh supervisor dalam memberikan tantangan (challenge) pengembangan sekolah kepada stakeholder pendidikan di sekolah. Tantangan ini harus dibuat serealistis mungkin agar mampu dicapai oleh pihak sekolah, berdasarkan situasi dan kondisi sekolah pada saat ini. Dengan demikian stakeholder tertantang untuk bekerjasama secara kolaboratif dalam rangka pengembangan mutu sekolah. Dimensi keempat dari hakikat pengawasan yaitu dimensi networking and collaboration. Dimensi ini menunjuk pada hakikat kegiatan pengawasan yang dilakukan oleh supervisor di mana supervisor itu sendiri harus mampu mengembangkan jejaring dan berkolaborasi antarstakeholder pendidikan serta seluruh komponen pendidikan lainnya dalam rangka meningkatkan produktivitas, efektivitas dan efisiensi pendidikan di sekolah.

Fokus dari keempat dimensi hakikat pengawasan itu dirumuskan dalam tiga aktivitas utama pengawasan yaitu: negosiasi, kolaborasi dan networking. Negosiasi dilakukan oleh supervisor terhadap stakeholder pendidikan dengan fokus pada substansi yang perlu dikembangkan atau ditingkatkan. Kolaborasi merupakan inti kegiatan supervisi yang harus selalu diadakan kegiatan bersama dengan pihak stakeholder pendidikan di sekolah binaannya. Hal ini penting karena muara untuk terjadinya peningkatan mutu pendidikan pada pihak sekolah.

Networking merupakan inti hakikat kegiatan supervisi yang prospektif untuk dikembangkan terutama pada era globalisasi dan cybernet teknologi seperti sekarang ini. Jejaring kerjasama dapat dilakukan baik secara horisontal maupun vertikal. Jejaring kerjasama secara horisontal dilakukan dengan sesama sekolah sejenis untuk saling bertukar informasi dan sharing pengalaman pengembangan mutu sekolah, misalnya melalui MKP, MKKS, MGBS, MGMP. Jejaring kerjasama secara vertikal dilakukan baik dengan sekolah pada aras 
di bawah nya sebagai pemasok siswa barunya, maupun dengan sekolah pada jenjang pendidikan lebih tinggi sebagai lembaga yang akan menerima para siswa lulusannya.

Berdasarkan uraian tersebut maka dapat disimpulkan bahwa pengawas sekolah atau pengawas satuan pendidikan adalah tenaga kependidikan profesional yang diberi tugas, tanggung jawab, dan wewenang secara penuh oleh pejabat yang berwewenang untuk melakukan pembinaan dan pengawasan pendidikan di sekolah baik pengawasan dalam bidang akademik (teknis pendidikan) maupun bidang manajerial (pengelolaan sekolah). Jabatan pengawas adalah jabatan fungsional bukan jabatan struktural sehingga untuk menyandang predikat sebagai pengawas harus berstatus tenaga pendidik/guru dan/atau kepala sekolah/wakil kepala sekolah, setidaktidaknya pernah menjadi guru.

Kemudian, Wiles \& Bondi (1986:11) mengatakan bahwa,

The role of the supervisor has many dimensions or facets, and for this reason supervision often overlaps with ad-ministrative, curricular and instructional functions. Each of these three dimensions are administration, curricu-lum, and instruction.

Berdasarkan uraian tersebut maka dimensi kepengawasan meliputi (1) administrasi, (2) kurikulum, (3) fungsi pengajaran, (4) pendukung, (5) percaya, (6) tantangan, dan (7) kolaborasi dan net $\neg$ work-ing. Beberapa dimensi tersebut merupakan serangkaian pengetahuan yang diperlukan oleh pengawas dalam melaksanakan tugasnya dalam membimbing, mengawasi dan membina serta bekerjasama dengan stakeholder pada sekolah binaan dalam mencapai tujuan dan/atau mutu sekolah sesuai dengan apa yang diperioritaskan bersama.

Kompetensi dan Bidang Pengawasan Pendidikan
Pengawas pendidikan memiliki kewenangan dan kemampuan profesional sebagai tenaga kependidikan. Kemampuan pengawas tidak hanya sebatas memberikan bantuan atau layanan dalam bentuk pemecahan masalah yang dihadapi guru dalam melakukan tugas pendidikan dan pengajaran, tetapi juga memberikan bantuan dan layanan kepada guru dalam masalah individu atau pribadi. Oleh karena itu, pengawas dibekali berbagai keterampilan tugas sesuai dengan bidangnya masing-masing yang berawal dari pengalaman dalam memecahkan masalah terkait dengan tugas pokok kepala sekolah dan guru. Wiles \& Bondi (1986:17-23) menyatakan bahwa bidangbidang khusus kompetensi pengawas dalam lingkup pendidikan, antara lain:

Supervisors are developer people, supervisors are curriculum developer, supervisors are instructional specialist, supervisors are human relations workers, supervisors are staff developers, super-visors are administrators, supervisors are managers of change, supervisiors are evaluators.

Berdasarkan bidang kompetensi yang dimiliki pengawas tersebut dapat disimpulkan bahwa: Pertama, pengawas memiliki kemampuan untuk memajukan siswa. Kedua, pengawas memiliki peluang untuk mempengaruhi pengembangan kurikulum. Ketiga, peran pengawas dalam pendidikan memiliki sekurang-kurang nya tiga dimensi, meliputi: penelitian, komunikasi dan pengajaran. Keempat, pengawas harus peka terhadap kebutuhan dari berbagai kelompok klien yang berinteraksi dengan mereka, sebagai pendengar yang sangat baik namun tidak hanya mendengar apa yang telah dikatakan melainkan juga apa yang dilakukan.

Kelima, pengawas hendaknya memiliki suatu model pelatihan bagi para guru yang telah direncanakan, seperti pelatihan untuk meningkatkan guru menjadi seorang instruktur. Keenam, pengawas sebagai seorang pengelola 
dalam pendidikan seyogyanya mampu berinteraksi dengan para pengelola pendidikan. Ketujuh, pengawas saat ini sering kali di anggap sebagai manajer perubahan yang berarti dan dianggap layak dalam tindakan-tindakannya. Kedelapan, menilai kinerja guru, hasil program, teks dan materi pembelajaran, kinerja konsultan, dan analisis pengujian merupakan bagian dari peran evaluasi.

Sedangkan, dalam Permendiknas No 12 tahun 2007 tentang kompetensi pengawas mengkategorikan:

kompetensi kepribadian, (2) kompetensi supervisi manajerial, (3) kompetensi supervisi akademik, (4) kompetensi evaluasi pendidikan, (5) kompetensi penelitian dan pengembangan. kompetensi sosial.

Dalam sistem pendidikan nasional, pendidikan dibedakan berdasarkan jalur, jenjang dan jenis pendidikan. Sudjana, et al. (2006:14) mengatakan bahwa berdasarkan jalur pendidikan, pendidikan dibedakan ke dalam jalur: (1) pendidikan formal/sekolah, (2) pendidikan nonformal dan (3) pendidikan informal. Berdasarkan jenjang pendidikan, pendidikan dibedakan ke dalam jenjang: (1) pendidikan dasar, (2) pendidikan menengah dan (3) pendidikan tinggi. Sedangkan berdasarkan jenis pendidikan, pendidikan dibedakan ke dalam jenis: (1) Pendidikan umum, (2) pendidikan kejuruan, (3) pendidikan akademik, (4) pendidikan vokasi, (5) pendidikan profesi, (6) pendidikan keagamaan dan (7) pendidikan khusus. Jalur, jenjang dan jenis pendidikan tersebut dapat diwujudkan dalam bentuk satuan pendidikan baik yang diselenggarakan oleh pemerintah dan atau oleh masyarakat.

Konsep kepengawasan tersebut terletak pada jalur pendidikan formal/sekolah dan ada pada jalur pendidikan nonformal. Pada jalur pendidikan formal disebut pengawas dan pada jalur pendidikan nonformal disebut penilik. Keduanya mempunyai peran yang sama yakni sebagai supervisor pendidikan. Dalam hal ini kepengawasan dimaknai dalam konteks pendidikan formal. Oleh sebab itu dibedakan menjadi pengawas TK/SD (pendidikan dasar) dan pengawas pendidikan menengah (SMPSMA-SMK). Mengingat pada pendidikan menengah diberlakukan guru mata pelajaran dan/atau bidang studi maka pengawas pada pendidikan menengah dikaitkan dengan mata pelajaran atau rumpun mata pelajaran.

Pengawas sekolah/pengawas satuan pendidikan berstatus sebagai pejabat fungsional yang berkedudukan atau ditempatkan di tingkat provinsi, kabupaten/kota bahkan di tingkat kecamatan untuk pengawas TK/SD. Seiring dengan berlakunya otonomi daerah maka status kepegawaian pengawas adalah pegawai negeri sipil daerah yang ditempatkan di kabupaten/kota atau provinsi.

Berdasarkan gambaran dan kondisi obyektif di lapangan saat ini, sudah saatnya dilakukan pembenahan tenaga pengawas mulai dari rekruitmen calon pengawas, tugas pokok dan fungsinya, kompetensi yang dipersyaratkan, pembinaan dan pengembangan serta penilaian kinerjanya dalam rangka peningkatan mutu pendidikan di sekolah yang menjadi binaannya.

Tugas Pokok dan Fungsi Pengawas Pendidikan

Pada dasarnya, tugas pengawas sekolah dalam lingkup pendidikan yaitu meningkatkan kinerja guru, agara guru dapat melaksanakan proses pembelajaran secara efektif dalam rangka mencapai tujuan pendidikan. Dalam kedudukannya sebagai pelakasana teknis untuk melakukan pengawasan pendidikan terhadap sejumlah sekolah yang ditunjuk, pengawas sekolah harus memahami, menghayati dan terampil di bidang tugasnya. Glickman, Gordon \& RossGordon (2007:11) menyatakan bahwa,

Supervisor have certain eduational tasks at their disposal that enable teachers to evaluate and modify their instruction...those supervisory tasks 
that have such potential to affect teacher development are direct assistance, group development, profesional development, curriculum development, and action research.

Pendapat tersebut dapat diartikan bahwa pengawas memiliki tugas tertentu dalam pendidikan yang memungkinkan guru untuk mengevaluasi dan merubah cara mengajar mereka. Tugas-tugas pengawasan yang memiliki potensi tersebut mampu mempengaruhi perkembangan guru meliputi: bantuan langsung, pengembangan kelompok, pengembangan profesional, pengembangan kurikulum, dan penelitian tindakan.

Selain itu, tindak lanjut ke depan, tugas pokok pengawas pendidikan sebagai supervisor pendidikan baik supervisi akademik maupun manajerial terdiri atas lima bidang, meliputi: 1) Monitoring/pemantauan, meliputi: memantau penjaminan standar mutu pendidikan, memantau pelaksanaan ujian, memantau rapat guru dan staf sekolah, memantau hubungan sekolah dengan masyaraka, memantau data statistik kemajuan sekolah, memantau programprogram pengembangan sekolah. 2) Supervisi, meliputi: mensupervisi kinerja sekoah, kinerja kepala sekolah dan aspek lainnya. 3) Peniliaian, meliputi: penilaian, pengolahan dan analisa data atas hasil belajar/bimbingan siswa dan kaitannya dengan faktor guru, mengumpulkan dan mengolah data sumber daya pendidikan, proses pembelajaran/bimbingan, lingkungan sekolah yang berpengaruh terhadap perkembangan hasil belajar/bimbingan siswa, melaksanakan analisis kompresif hasil penilaian sebagai bahan untuk melakukan inovasi pendidikan di sekolah binaan. 4) Pembinaan/pengembangan, meliputi: memberikan bantuan dan bimbingan kepada guru, membina pelaksanaan pengelolaan sekolah, kepala sekolah dan staf sekolah dalam meningkatkan kinerja sekolah, kepada orang tua siswa dan komite sekolah. 5) Pelaporan dan tindak lanjut, meliputi: melaporkan perkembangan dan hasil pengawasan kepada kepala Dinas Pendidikan Kabupaten/Kota, Provinsi dan/atau Nasional.

Berdasarkan beberapa tugas pokok tersebut maka dapat dikatakan bahwa kegiatan yang dilakukan oleh pengawas meliputi: (1) Menyusun program kerja kepengawasan untuk setiap semester dan setiap tahunnya pada sekolah yang dibinanya. (2) Melaksanakan penilaian, pengolahan dan analisis data hasil belajar/bimbingan siswa dan kemampuan guru. (3) Mengumpulkan dan mengolah data sumber daya pendidikan, proses pembelajaran/bimbingan, lingkungan sekolah yang berpengaruh terhadap perkembangan hasil belajar/bimbing $\neg$ an siswa. (4) Melaksanakan analisis komprehensif hasil analisis berbagai faktor sumber daya pendidikan sebagai bahan untuk melakukan inovasi sekolah. (5) Memberikan arahan, bantuan dan bimbingan kepada guru tentang proses pembelajaran/bimbingan yang bermutu untuk meningkatkan mutu proses dan hasil belajar/bimbingan siswa. Melaksanakan penilaian dan monitoring penyelenggaran pendidikan di sekolah binaannya mulai dari penerimaan siswa baru, pelaksanaan pembelajaran, pelaksanaan ujian sampai kepada pelepasan lulusan/pemberian ijazah. (7) Menyusun laporan hasil pengawasan di sekolah binaannya dan melaporkannya kepada Dinas Pendidikan, Komite Sekolah dan stakeholder pendidikan. (8) Melaksanakan penilaian hasil pengawasan seluruh sekolah sebagai bahan kajian untuk menetapkan program kepengawasan semester berikutnya. (9) Memberikan bahan penilaian kepada sekolah dalam rangka akreditasi sekolah. Memberikan saran dan pertimbangan kepada pihak sekolah dalam memecahkan masalah yang dihadapi sekolah berkaitan dengan penyelenggaraan pendidikan. 
Peran Pengawas Pendidikan

Selain tugas pokok dan fungsi yang dimiliki oleh pengawas, pengawas juga memiliki peranan dalam meningkatkan mutu pendidikan. Secara garis besar peran pengawas pendidikan tertulis dalam Peraturan Pemerintah nomor 19 tahun 2005 tentang Standar Nasional Pendidikan pada pasal 55 bahwa "pengawasan pendidikan meliputi pemantauan, supervisi, evaluasi, pelaporan, dan tindak lanjut hasil pengawasan". Kemudian, Dharma (2008:4) mengemukakan bahwa pengawas sekolah atau pengawas pendidikan hendaknya berperan sebagai:

(1) Mitra guru dalam meningkatkan mutu proses dan hasil pembelajaran dan bimbingan di sekolah binaannya. (2) Inovator dan pelopor dalam mengembangkan inovasi pembelajaran dan bimbingan di sekolah binaannya. (3) Konsultan pendidikan di sekolah binaannya. (4) Konselor bagi kepala sekolah, guru dan seluruh staf sekolah. (5) Motivator untuk meningkatkan kinerja semua staf sekolah.

Lebih lanjut, Dharma (2008:5) mengatakan bahwa pengawas sekolah memiliki peran khusus dalam melaksanakan supervisi manajerial, meliputi: (1) conceptor, (2) programmer, (3) composer, (4) reporter, (5) builder, (6) supporter, (7) observer dan (8) user.

Selain itu, Olivia (Sahertian, 2000: 25) mengemukakan bahwa "peran seorang supervisor adalah sebagai: (1) coordinator, (2) consultant, (3) leadership group dan, (4) evaluator". Pendapat tersebut dapat disimpulkan bahwa pengawas sebagai koordinator pengawas dapat mengkoordinasikan program pembelajaran, tugas-tugas anggota staf sebagai kegiatan yang berbeda-beda diantara guru. Kemudian sebagai seorang konsultan, pengawas dapat memberikan bantuan, mengkonsultasikan masalah yang dialami oleh guru baik secara individu maupun secara kelompok. Sebagai pemimpin kelompok, pengawas dapat memimpin sejumlah staf/guru dalam mengembangkan potensi kelompok, mengembangkan kurikulum, materi pelajaran dan kebutuhan profesioanl secara bersama. Sebagai pemimpin kelompok, pengawas sekolah dapat mengembangkan keterampilan dan kiatkiat dalam bekerja untuk kelompok (working for the group), bekerja dengan kelompok lain (working with other group) dan bekerja melalui kelompok (working through the group). Sementara sebagai evaluator, seorang pengawas dapat membantu para guru dalam menilai hasil proses belajar mengajar dan menilai kurikulum yang dikembangkan oleh sekolah sesuai dengan kurikulum pada standar nasional pendidikan.

$$
\text { Wiles \& Bondi }
$$

menjelaskan tentang peran pengawas bahwa,

We have observed that this important educational role sits at the juncture of most communication and decision making in school setting. Supervisor link district office with school and classroom. They also represent a highly aducated profesional who can provide resource and knowledge to teachers and other leaders in the school system.

Pendapat Wiles \& Bondi tersebut dapat diartikan bahwa peran penting pendidikan terletak pada komunikasi dan pengambilan keputusan dalam mengatur sekolah. Supervisor atau pengawas merupakan penghubung antara kantor distrik dengan sekolah dan kelas. Mereka juga mewakili pendidik profesional yang lebih tinggi yang dapat memberikan sumber daya dan pengetahuan bagi guru serta kepala sekolah.

Berdasarkan uraian tersebut bahwa peranan tidak dapat dipisahkan (inherent) dengan fungsi. Secara konseptual peranan adalah orang yang memainkan fungsi, sedangkan fungsi adalah kegiatan atau proses yang harus dimainkan oleh pemeran. Jadi, peranan harus berkaitan dengan fungsi atau sebaliknya fungsi berkaitan dengan peranan. Atas rasional tersebut, maka fungsi umum dan fungsi 
khusus pengawas pendidikan harus berkorelasi dengan peranan umum dan peranan khusus seperti yang telah diutarakan tersebut. Fungsi umum dan fungsi khusus pengawas pendidikan secara langsung maupun tidak langsung dalam dunia pendidikan dapat meningkatkan mutu pendidikan dengan menjalankan peran yang diamanahkan. Peran pengawas pendidikan dapat disimpulkan sebagai berikut: (1) observer, (2) supervisor, (3) evaluator, dan (4) penindak lanjut. Sedangkan peran khusus pengawas sekolah/madrasah (pengawas pendidikan) adalah sebagai: (1) partner, (2) inovator, (3) consultant, (4) conselor, (5) motivator, (6) conceptor, (7) programmer, (8) composer, (9) reporter, (10) builder, (11) supporter, (12) user, (13) coordinator dan (14) leadership group.

Dengan demikian, beberapa peran dan tugas pokok dan fungsi pengawas tersebut dapat dijadikan acuan bagi seorang pengawas pendidikan dalam menjalankan tugas kepengawasan sesuai dengan peraturan perudangan yang berlaku di sekolah binaan.

\section{Mutu Pendidikan}

Upaya peningkatan mutu pendidikan menjadi prioritas utama dalam program pendidikan nasional pada saat ini. Peningkatan mutu pendidikan merupakan tugas berat dan bukan hanya menjadi tanggung jawab pemerintah tetapi merupakan tanggung jawab bersama antara pemerintah dan masyarakat. Glassman, Naidoo \& Wood (2007:5) menyatakan bahwa,

Communities can mobilize to address successfully the access issue; improving quality in the classroom environment, in children's learning, in support for teachers on the job is a slower, far more difficult process.

Definisi tersebut dapat diartikan bahwa masyarakat dapat memobilisasi untuk mengatasi masalah akses dengan sukses, meningkatkan kualitas dalam lingkungan kelas, dalam pembelajaran anak-anak, dalam dukungan guru pada pekerjaan yang lebih ringan, dan proses sulit yang lebih jauh. Dengan demikian dapat dikatakan bahwa mutu tidak bisa berdiri sendiri namun memerlukan kerjasama yang sinergi dari beberapa komponen yang terlibat langsung maupun tidak langsung pada bidang pendidikan.

Di samping itu, pemerintah mengeluarkan Peraturan Pemerintah Nomor 19 Tahun 2005 tentang Standar Nasional Pendidikan. Standar Nasional Pendidikan dalam Peraturan Pemerintah Nomor 19 Tahun 2005 merupakan kriteria minimal tentang sistem pendidikan diseluruh wilayah hokum Negara Kesatuan Republik Indonesia. Dalam Bab II pasal 2 PP No. 19 Tahun 2005 tentang Standar Nasional Pendidikan dinyatakan bahwa lingkup Standar Nasional Pendidikan (2005:4) menguraikan bahwa, (1) standar isi, (2) standar proses, (3) standar kompetensi kelulusan, (4) standar pendidik dan tenaga kependidikan, (5) standar sarana prasarana, (6) standar pengelolaan, (7) standar pembiayaan, dan (8) standar penilaian pendidikan.

Dengan adanya delapan Standar Nasional Pendidikan tersebut, maka setiap pengelolaan sekolah atau lembaga pendidikan harus mampu memenuhi standar tersebut dan/atau minimal mengelola pendidikan sesuai dengan parameter yang telah ditetapkan oleh pemerintah sehingga mencapai mutu pendidikan yang diharapakan.

Mutu pendidikan tidak akan berhasil jika dicapai karena faktor guru saja. Tenaga pendidikan lainya seperti pengawas juga memberikan kontribusi yang signifikan untuk meningkatkan mutu pendidikan. Disadari ataupun tidak disadari, mutu pengawasan akan mempengaruhi mutu guru, mutu guru akan mempengaruhi mutu proses pembelajaran, proses pembelajaran yang bermutu akan menghasilkan murid yang bermutu, dan pada akhirnya jika semua bersinergi akan mempengaruhi mutu pendidikan secara keseluruhan. Hal 
tersebut sebagaimana ditegaskan oleh Carnegie (Lovat \& Toomey, 2009:4) bahwa,

Quality teaching defined in Carnegie (1996) imply that it is not just the surface factual learning so characteristic of education of old that is to be superseded but it is surface learning in general that is to be surpassed in favour of a learning that engages the whole person in depth of cognition, social and emotional maturity, and self-knowledge.

Pemikiran ini diartikan bahwa kualitas pengajaran yang didefinisikan Carnegie diimplikasikan bahwa tidak hanya terdapat pada permukaan pembelajaran faktual tetapi karakteristik dari pendidikan lama yang akan digantikan, pada umumnya pembelajaran harus melampaui dan mendukung pembelajaran yang melibatkan keseluruhan pribadi dalam kedalaman kognisi, kematangan sosial dan emosional, dan pengetahuan diri.

Dengan demikian, sangat beralasan, bahwa secara ekstrem pernah dikemukakan para ahli supervisi atau pengawasan, bahwa keberhasilan suatu bangsa ditentukan oleh bagaimana kinerja pengawas pendidikannya. Hal ini merupakan suatu pandangan yang cukup berani karena bangsa-bangsa tertentu menjadikan pendidikan sebagai leading sector dalam pembangunan sumber daya manusianya. Oleh karena itu, keprofesian pengawas menjadi krusial untuk dimiliki agar dapat memberikan manfaat bagi pendidikan dan pengajaran.

Pengawas yang bermutu adalah pengawas yang dapat memberikan bantuan peningkatan mutu pembelajaran bagi guru. Guru yang bermutu adalah guru yang dapat meningkatkan kemampuan peserta didiknya dalam menyerap pelajaran sesuai dengan standar kompetensi yang ditetapkan.
Faktor yang Mempengaruhi Mutu Pendidikan

Pendidikan bermutu lahir dari sistem perencanaan yang baik (good planning system) dengan materi dan sistem tata kelola yang baik (good governance system) dan disampaikan oleh guru yang baik/cerdas (good teacher) dengan komponen pendidikan yang bermutu pula. Mulyasana (2011:120-123) menyebutkan bahwa terdapat "beberapa faktor dalam upaya menciptakan pendidikan yang bermutu, antara lain: (1) materi yang baik. (2) perencanaan pendidikan yang baik. (3) tata kelola pendidikan yang baik. (4) pendidikan yang bermutu lahir dari guru yang bermutu.

Selanjutnya, Zamroni (2011:158) menyatakan bahwa "peningkatan mutu adalah memperkuat penekanan sekolah sebagai suatu entitas mandiri, sebagai implikasi dari kebijakan SBM dan KTSP". Selebihnya Zamroni (2011:159) menggambarkan beberapa faktor-faktor dalam upaya peningkatan mutu pendidikan.

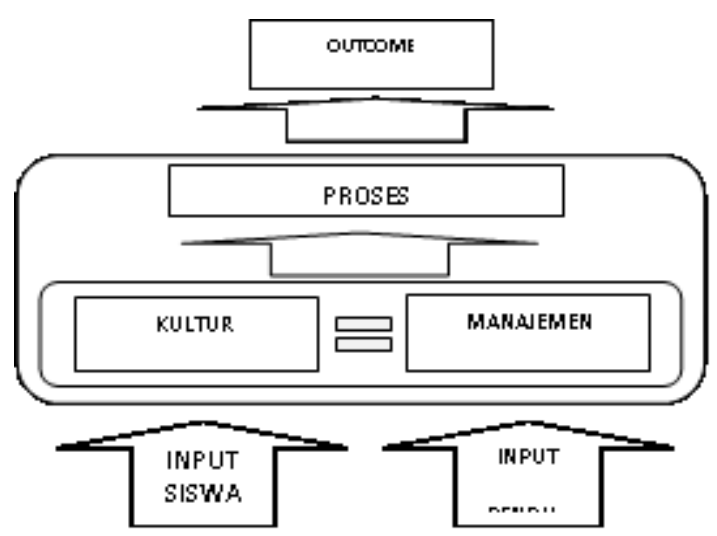

Gambar 1. Faktor Peningkatan Mutu (Zamroni, 2011:159)

Berdasarkan gambar tersebut dapat dikatakan bahwa keberlangsungan proses pendidikan mencakup tiga komponen utama meliputi proses pembelajaran, manajemen sekolah dan kultur sekolah. Ketiga komponen tersebut saling mebutuhkan antara satu sama lain dalam mempengaruhi peningkatan mutu pendidikan. Namun, keseluruhan faktor 
tersebut tidak lepas dari peran seorang kepala sekolah sebagai pimpinan tertinggi di sekolah dalam mengelola sekolah dan memfasilitasi proses pembelajaran untuk menarik perhatian guru dalam mengajar serta menarik perhatian peserta didik untuk belajar. Dengan demikian, peran pengawas pendidikan dalam supervisi akademik dan manajerial benar-benar harus mampu menciptakan kepala sekolah yang kompeten dalam mengelola sekolahnya.

\section{METODE}

Penelitian ini merupakan jenis penelitian kualitatif dengan pendekatan studi kasus. Studi kasus menggambarkan ciri-ciri suatu kasus dimana kasus tersebut bersifat kontemporer, masih terkait dengan masa kini, baik yang sedang terjadi, maupun telah selesai tetapi masih memiliki dampak yang masih terasa pada saat dilakukannya penelitian. Penelitian jenis penelitian kualitatif dengan pendekatan studi kasus untuk mengungkap tentang fakta dibalik fenomena tentang proses perekrutan pengawas pendidikan, peran pengawas pendidikan untuk meningkatkan mutu pendidikan di Kabupaten Bima Provinsi Nusa Tenggara Barat dan faktor-faktor yang menjadi kendala dan pendukung pengawas pendidikan dalam melaksanakan perannya.

Penelitian ini dilaksanakan di Kabupaten Bima Provinsi Nusa Tenggara Barat selama kurun waktu dua bulan dimulai dari bulan Februari sampai dengan Maret 2014 sesuai dengan beberapa pertimbangan, meliputi: jumlah pengawas pendidikan tidak sesuai dengan jumlah guru; pengawas pendidikan memiliki kualifikasi pendidikan yang beragam; mobilitas pengawas pendidikan ke sekolah binaan mengalami banyak hambatan; jumlah sekolah di Kabupaten Bima sebanyak delapan puluh sekolah SMP Negeri meliputi sekolah di wilayah distrik perkotaan dan distrik terpencil.

Subjek dalam penelitian ini adalah Kepala Dinas Pendidikan (diwakili
Sekretaris Dinas Pendidikan), Koordinator Pengawas Pendidikan, Sekretaris Pengawas Pendidikan, Pengawas SMP, Kepala Sekolah, Kepala Bidang Pendidikan Menengah, Kepala Seksi Kurikulum, dan guru. Beberapa dari subjek penelitian tersebut dibagi menjadi dua kategori, meliputi: key informan (kepala sekolah) dan informan. Teknik pengumpulan data menggunakan wawancara, observasi, studi dokumen. Instrumen pengumpulan data dalam penelitian kualitatif adalah peneliti. Keabsahan data menggunakan uji credibility dan confirmability. Peneliti melakukan uji credibility untuk meningkatkan kepercayaan terhadap data melalui member check, triangulasi sumber dan triangulasi teknik. Kemudian, analisis data dalam penelitian menggunakan tahapan analisis model interaktif dari Miles \& Humberman dan analisis kompensial dari Spradley.

\section{HASIL DAN PEMBAHASAN}

Hasil temuan tentang peran pengawas pendidikan dalam peningkatan mutu pendidikan SMP di Kabupaten Bima Provinsi Nusa Tenggara Barat.

Proses Perekrutan Pengawas Pendidikan di Kabupaten Bima

Proses perekrutan pengawas pendidikan dalam peningkatan mutu pendidikan SMP di Kabupaten Bima meliputi: pengangkatan langsung (kebijakan) oleh Bupati; track record; rekomendasi dari UPT Kecamatan Kecamatan dan Kepala Dinas DIKPORA; kebutuhan Dinas DIKPORA; pengawas pendidikan juga diangkat dari guru-guru senior; pejabat struktural sebagai top leader di berbagai instasi pemerintahan. Namun, dari keseluruhanya itu, perekrutan pengawas idealnya memiliki syarat dan kriteria sebagaimana tertulis dalam Permendiknas nomor 12 tahun 2007. 
Peran Pengawas Pendidikan dalam Memantau Pelaksanaan Program Sekolah untuk Meningkatkan Mutu Pendidikan SMP di Kabupaten Bima

Peran pengawas pendidikan dalam memantaun program kerja sekolah pada pemantauan proses belajar mengajar meliputi pemantauan langsung cara mengajar guru di kelas, supervisi alat-alat pembelajaran, administrasi pembelajaran (RPP, Silabus, daftar nilai, dll). Kemudian, pemantauan pelaksanaan ujian sekolah dan ujian nasional meliputi: administrasi pelaksanaan ujian sekolah/nasional (juklak/juknis); persiapan pelaksanaan ujian; pelaksanaan ujian; try out; les-les tambahan. Selanjutnya, pemantauan tertitik dan rapat guru dan staf meliputi: hasil rapat guru; buku rapat; pemberian arahan; pembinaan pada kepala sekolah, guru dan TU; pemberian solusi untuk meningkatkan mutu sekolah. Selain itu, pengawas juga memantau hubungan sekolah dengan masyarakat meliputi: RKS sekolah dengan komite, hasil kerja sekolah. Selebihnya, data statistik sekolah untuk melihat ketercapaian sekolah juga tidak terlepas dari pantauan pengawas pendidikan, meliputi: statistik kelulusan tiap tahun; statistik kehadiran siswa; statistik kinerja sekolah. Disamping itu, pemantauan mutu akademik dan non-akademik meliputi: jadwal kegiatan belajar; jadwal kegiatan ekstrakurikuler; prestasi siswa. Sementara, pemantaun terhadap pemanfaatan sumber daya meliputi: penyusunan RKS, administrasi guru, aktivitas pembelajaran.

Peran Pengawas Pendidikan dalam Mensupervisi Guru untuk Meningkat-kan Mutu Pendidikan SMP di Kabupaten Bima

\section{Program Kepengawasan}

Peran pengawas pendidikan dalam mensupervisi guru untuk meningkatkan mutu pendidikan SMP di Kabupaten Bima idealnya memerlukan program pengawasan. Temuan penelitian terkait program pengawasan meliputi: pembuatan rencana pelaksanaan pengawasan (kepengawasan manajerial dan akademik), program tahunan, program semester, sosialisasi program kepengawasan secara lisan pada kepala seklolah dan guru yang dikumpulkan pada satu ruangan ketika awal semester di masing-masing sekolah binaan.

Latar Belakang Pendidikan Pengawas Pendidikan yang Mensupervisi Guru

Peran pengawas pendidikan dalam mensupervisi guru untuk meningkatkan mutu pendidikan SMP di Kabupaten Bima idealnya membutuhkan pengawas pendidikan yang memiliki latar belakang pendidikan yang sama dengan guru ketika melaksanakan supervisi, tetapi tidak menutup kemungkinan pengawas pendidikan yang mempunyai latar belakang pendidikan dengan guru yang disupervisi tidak mampu melakukan tugas namun pelaksanaan supervisi hanya tertitik pada pembinaan administrasi pelajaran.

Intensitas Kunjungan Pengawas Pendidikan dalam Melaksanakan Supervisi

Peran pengawas pendidikan dalam mensupervisi guru untuk meningkatkan mutu pendidikan SMP di Kabupaten Bima idealnya berkunjung untuk melakukan supervisi sesuai dengan yang tertulis berdasarkan Peraturan Pemerintah Nomor 74 tahun 2008 tentang Guru Pasal 54 ayat (8) dan (9) bahwa pengawas terdiri dari pengawas satuan pendidikan, pengawas mata pelajaran, atau pengawas kelompok mata pelajaran. Ruang lingkup tugas pengawas adalah melakukan pembimbingan dan pelatihan profesional guru dan pengawasan yang ekuivalensinya dengan 24 (dua puluh empat) jam pembelajaran tatap muka dalam 1 (satu) minggu dan paling sedikit 37.5 jam dalam satu minggu. Namun temuan menggambarkan bahwa pengawas pendidikan dalam melakukan perannya ketika berkunjung ke sekolah binaannya lebih intens pada sekolah binaan yang jaraknya relatif dekat dengan tempat domisilinya sementara 
sekolah yang lokasinya jauh dengan tempat domisili hanya berkunjung sebanyak satu sampai dua kali per semester.

\section{Pelaksanaan Supervisi}

Peran pengawas pendidikan dalam mensupervisi guru untuk meningkatkan mutu pendidikan SMP di Kabupaten Bima meliputi: pembuatan jadwal supervisi di setiap sekolah binaan hanya untuk personal pengawas; sosialisasi pelaksanaan supervisi hanya secara lisan; tidak ada jadwal khusus dalam melaksanakan supervisi; supervisi dilakukan secara spontan (mendadak); langkah-langkah melakukan supervisi yaitu membaca buku supervisi yang dilakukan kepala sekolah, mensupervisi administrasi pelajaran, mensupervisi langsung di dalam kelas, menggunakan isntrumen supervisi; beberapa mata pelajaran terkadang tidak pernah disupervisi; supervisi secara periodik pada sekolah yang relatif dekat dengan tempat domisili pengawas; pelaksanaan supervisi di daerah yang relatif jauh dilakukan di rumah kepala sekolah (supervisi administrasi pelajaran) dan supervisi gabungan secara keselurahan (kepala sekolah, guru dan TU).

Peran Pengawas Pendidikan dalam Mengevaluasi Program Kerja Sekolah untuk Meningkatkan Mutu Pendidikan SMP di Kabupaten Bima

Peran pengawas pendidikan dalam mengevaluasi program kerja sekolah untuk meningkatkan mutu pendidikan SMP di Kabupaten Bima meliputi evaluasi kinerja kepala sekolah, evaluasi knerja tenaga pendidik (guru) dan evaluasi kinerja tenaga kependidikan. Evaluasi kinerja kepala sekolah tertitik pada evaluasi kompetensi kepala sekolah meliputi kompetensi kepribadian, manajerial, kewirausahaan, dan EMASLIM (edukator, manager, administrator, supervisor, leader, inovator, motivator). Evaluasi kinerja kepala sekolah menggunakan instrumen evaluasi kinerja kepala sekolah. Sementara, evaluasi pada kinerja guru tertitik pada evaluasi perangkat pembelajaran seperti program semester, program tahunan, cara mengajar. Evaluasi kinerja guru juga menggunakan instrumen evaluasi kinerja guru. Selebihnya evaluasi pada tenaga kependidikan hanya bersifat pembinaan dalam melaksanakan tugos pokok dan fungsinya, karena evaluasi pada tenaga kependidikan harus melalui rekomendasi dari kepala sekolah karena tenaga kependidikan merupakan bawahan kepala sekolah secara garis komando.

Peran Pengawas Pendidikan dalam Membuat Laporan Hasil Pemantauan, Supervisi dan Evaluasi pada Sekolah Binaan untuk Meningkatkan Mutu Pendidikan SMP di Kabupaten Bima

Peran pengawas pendidikan dalam membuat laporan hasil pemantauan, supervisi dan evaluasi pada sekolah binaan untuk meningkatkan mutu pendidikan SMP di Kabupaten Bima meliputi pembuatan laporan yang berdasarkan hasil temuan dengan menggunakan metode observasi, interview, analisa dokumen, dan brainstroming; laporan memuat tentang temuan akan kekurangan maupun kelemahan kepala sekolah, pendidik dan tenaga kependidikan; laporan juga memuat hasil evaluasi kompetensi guru; pembuatan laporan dalam bentuk softcopy dan hardcopy; kemudian, pengawas selalu membuat laporan yang mana diberikan ke Korwas dan Dinas DIKPORA, namun laporan tidak diberikan ke sekolah binaan tetapi hanya diinformasikan melalui surat edaran kepala Dinas DIKPORA.

Peran Pengawas Pendidikan dalam Memberikan Tindak Lanjut untuk Meningkatkan Mutu Pendidikan SMP di Kabupaten Bima

Peran pengawas pendidikan dalam memberikan tindak lanjut untuk meningkatkan mutu pendidikan SMP di Kabupaten Bima meliputi: tindak lanjut berupa pemberian arahan bersifat lisan 
atas kekurangan guru dalam proses pembelajaran dan bersifat tertulis ketika pemeriksaan administrasi pelajaran; pengawas pendidikan masih sangat kurang dalam menindak lanjut kembali hasil supervisi pada sekolah di daerah yang letaknya relatif dekat maupun jauh dari tempat domisili.

Faktor Penghambat Peran Pengawas Pendidikan untuk Meningkatkan Mutu Pendidikan SMP di Kabupaten Bima

Faktor penghambat peran pengawas pendidikan untuk meningkatkan mutu pendidikan SMP di Kabupaten Bima meliputi: letak geografis; akses jalan; fasilitas ruang kerja pengawas; fasilitas sekolah; penguasaan IT; SDM (pengawas pendidikan, tenaga pendidik dan tenaga kependidikan).

Faktor Pendukung Peran Pengawas Pendidikan untuk Meningkatkan Mutu Pendidikan SMP di Kabupaten Bima

Faktor pendukung peran pengawas pendidikan untuk meningkatkan mutu pendidikan SMP di Kabupaten Bima meliputi: dukungan dari pemerintah berupa motor dinas; tunjangan tambahan operasional dari Pemerintah Daerah; tempat domisili; semangat kerja pengawas pendidikan; pelatihan dalam peningkatan kompetensi; siswa; guru dan sarana/ prasarana di sekolah.

\section{PENUTUP}

Simpulan

Adapun kesimpulan dari penelitian ini yaitu: pertama, proses perekrutan pengawas pendidikan di Kabupaten Bima belum sepenuhnya dilaksanakan sesuai dengan peraturan pemerintah atau undangundang tentang pengawas pendidikan/pengawas sekolah. Kedua, pengawas pendidikan dalam memantau pelaksanaan program sekolah untuk meningkatkan mutu pendidikan SMP di Kabupaten Bima belum optimal karena sekolah yang ada di daerah yang relatif jauh masih dipantau satu sampai dua kali dalam kurun waktu satu semester bahkan satu tahun. Ketiga, peran pengawas pendidikan dalam mensupervisi guru untuk meningkatkan mutu pendidikan SMP di Kabupaten Bima belum optimal karena sekolah yang ada di daerah relatif jauh terkadang disupervisi pada administrasi pelajaran, pelaksanaan supervisi guru digabung dengan supervisi kepala sekolah, dan terkadang pelaksanaan supervisi dilakukan di rumah kepala sekolah. Kemudian, yang keempat, peran pengawas pendidikan dalam mengevaluasi program kerja sekolah untuk meningkatkan mutu pendidikan SMP di Kabupaten Bima sudah terlaksana dengan baik, hal ini dapat dilihat bahwa pengawas pendidikan menggunakan instrumen standar/baku sebagai acuan evaluasi. Kelima, peran pengawas pendidikan dalam membuat laporan hasil pemantauan, supervisi, dan evaluasi terlaksana dengan baik, hal ini dilihat dari laporan temuan pengawas pendidikan dilaporkan kepada kepala Dinas DIKPORA dan diinformasikan kepada seluruh sekolah di Kabupaten Bima melalui surat edaran kepala Dinas DIKPORA. Keenam, peran pengawas pendidikan dalam memberikan tindak lanjut untuk meningkatkan mutu pendidikan SMP di Kabupaten Bima belum optimal, hal ini ditandai bahwa pengawas pendidikan hanya memberikan wejangan atau pembinaan kepada guru setelah supervisi tentang kelemahankelemahan selama proses pembelajaran dan belum menyentuh secara langsung pada tindakan supervisi kembali di dalam kelas untuk melihat kekurangankekurangan yang telah diperbaiki. Ketujuh, faktor penghambat peran pengawas untuk meningkatan mutu pendidikan SMP di kabuapaten Bima antara lain: letak geografis, akses jalan, fasilitas (ruang kerja pengawas pendidikan dan sekolah), penguasaan IT, SDM (pengawas pendi-dikan, tenaga pendidik, kependidikan). Kedelapan, faktor pendukung peran pengawas pendidikan untuk meningkatan mutu pendidikan SMP di Kabupaten Bima antara lain: dukungan 
dari pemerintah berupa motor dinas, tunjangan tambahan operasional dari Pemerintah Daerah, tempat domisili, semangat kerja pengawas pendidikan, pelatihan dalam peningkatan kompetensi, siswa, keterlibatan masya-rakat, guru, sarana/prasarana di sekolah.

Saran

Berdasarkan temuan penelitian tentang peran pengawas pendidikan dalam peningkatan mutu pendidikan di Kabupaten Bima maka dapat disarankan kepada: pertama, Dinas Pendidikan, Pemuda dan Olahraga (DIKPORA) Kabupaten Bima hendaknya mampu merekrut pengawas pendidikan sesuai dengan acuan atau kriteria yang mengatur tentang pengawas pendidikan dan memperhatikan temuan pengawas pendidikan pada semua sekolah binaan sehingga temuan tersebut dapat dijadikan sebuah kebijakan dalam mengambil sebuah keputusan, memperhatikan fasilitas ruangan pengawas, dan memperhatikan biaya operasional pengawas dalam melaksanakan tugas pokok dan fungsinya. Kedua, koordinator pengawas pendidikan hendaknya lebih tegas lagi kepada pengawas pendidikan dalam rangka membuat program kerja kepengawasan, mengorganisasikan personil pengawas pendidikan dengan baik dalam mengikuti pelatihan kepengawasan sehingga mampu menciptakan pengawas yang profesional dan kompeten. Ketiga, pengawas pendidikan hendaknya menyadari tugas pokok dan fungsinya sebagai jabatan fungsional paling tinggi pada tingkat pendidikan dasar dan menengah, meningkatkan tugas pokok dan fungsinya pada daerah terpencil sehingga mampu memberikan pembinaan pada sekolah binaan secara merata. Kemudian yang keempat, kepala sekolah diharapkan mampu mendiskusikan tentang beberapa permasalahan yang timbul di sekolah dengan pengawas pendidikan sehingga hal-hal yang masih di luar batas kemampuan kepala sekolah dapat diatasi bersama melalui pembinaan pengawas pendidikan. Kelima, guru harus menyadari bahwa peran pengawas pendidikan merupakan mitra atau partner kerja dalam pelaksanaan proses pembelajaran, sehingga jika ditemui pengawas pendidikan di sekolah, hendaknya guru mempunyai inisiatif untuk berkonsultasi tentang kekurangan yang masih dinilai ada pada proses pembelajaran baik dari aspek cara mengajar, pengelolaan kelas, penulisan karya ilmiah, serta pembuatan administrasi pembelajaran yang pada akhirnya mampu meningkatkan keprofesionalan seorang guru pada masa yang akan datang.

\section{DAFTAR PUSTAKA}

Alarcão, I. (2007). Teacher education and supervision: A new scope. Conference given at the Faculty of Psychology and Educational Sciences of the University of Lisbon, 3 May 2007. Sísifo. Educational Sciences Journal, 08:p 109118.

Depdiknas. (2007). Permendiknas nomor 12 Tahun 2007 tentang standar pengawas Sekolah/Madrasyah. Jakarta: Depdiknas.

Dharma, S. (2008). Peran dan fungsi pengawas sekolah/madrasah. Jurnal tenaga kependidikan. Jakarta: Direktorat Tenaga Kependidikan dan Direktorat Jenderal Peningkatan Mutu Pendidik dan Tenaga Kependidikan. Kementrian Pendidikan Nasional.

Glassman, D., Naidoo, J., \& Wood, F. (2007). Community schools in Africa: Reaching the Unreached. New York: Springer.

Glickman, C. D., Gordon, S. P., \& RossGordon, J. M. (2007). Supervision and Instructional Leadership: A Developmental Approach ( $7^{\text {th }}$ ed). New York: Pearson.

Lovat, T., \& Toomey, R. (2009). Values Education and Quality Teaching. Australia: Springer 
Mulyasana, D. (2011). Pendidikan

Bermutu dan Berdaya Saing. Bandung: PT Remaja Rosdakarya.

Presiden RI. (2005). Peraturan Pemerintah RI Nomor 19, Tahun 2005, tentang Standar Nasional Pendidikan. Jakarta: Depdiknas.

Sahertian, P. A. (2000). Konsep Dasar dan Teknik Supervisi Pendidikan. Jakarta: Rineka Cipta

Sudjana, N., et al. (2006). Standar Mutu Pengawas. Jakarta: Direktorat Jenderal Peningkatan Mutu Pendidik dan Tenaga Kependidikan Direktorat Tenaga Kependidikan Departemen Pendidikan Nasional

Sullivan, S. \& Glanz, J. (2005). Supervison that Improves Teaching: Strategies and Technique ( $\left.2^{\text {nd }} e d\right)$. Califronia: Sage Publications.

Wiles, J., \& Bondi. J. (1986). Supervision a Guide to Practice ( $2^{\text {nd }} e d$ ). London: A Bell\&Howell Company.

Zamroni. (2011). Dinamika Peningkatan Mutu. Yogyakarta: Galvin Kalam Utama. 